\title{
Awareness about cervical cancer risk factors and symptoms
}

\author{
Sadhana Singh ${ }^{1}$, Nutan Narayan ${ }^{2}$, Rupam Sinha ${ }^{3}$, \\ Pragya Sinha $^{4}$, Virendra Prasad Sinha ${ }^{5}$, Jayshree J. Upadhye ${ }^{1 *}$
}

\begin{abstract}
${ }^{1}$ Department of Obstetrics and Gynecology, Narayan Medical College and Hospital, Jamuhar, Bihar, India ${ }^{2}$ Department of Obstetrics and Gynecology, Nalanda Medical College and Hospital, Patna, Bihar, India ${ }^{3}$ Department of Obstetrics and Gynecology, Patna Medical College and Hospital, Patna, Bihar, India ${ }^{4}$ Department of Radiology, TMC, Muradabad, Uttar Pradesh, India

${ }^{5}$ Department of Cardiology, Patna Medical College and Hospital, Patna, Bihar, India
\end{abstract}

Received: 26 September 2018

Accepted: 22 October 2018

\section{*Correspondence:}

Dr. Jayshree J. Upadhye,

E-mail: jayshreeupadhye@gmail.com

Copyright: (C) the author(s), publisher and licensee Medip Academy. This is an open-access article distributed under the terms of the Creative Commons Attribution Non-Commercial License, which permits unrestricted non-commercial use, distribution, and reproduction in any medium, provided the original work is properly cited.

\section{ABSTRACT}

Background: Lack of awareness of risk factors and symptoms for cancer may leads to late diagnosis and poor prognosis. A Cross-sectional population-based survey was conducted to assess community awareness about cervical cancer risk factors and symptoms and perceptions about prevention and cure of cervical cancer.

Methods: The cross-sectional study included 200 married women aged 18 years and above who consented for the study.

Results: In present study, out of 200 respondents, the risk factors for cervical carcinoma known to females were HPV infection in $30(15 \%)$, multiparity and reproductive tract infection in $24(12 \%)$ each, frequent childbirth in $22(11 \%)$, early marriage in $18(9 \%)$ and multiple sexual partners in $12(6 \%) .158(79 \%)$ females knew vaginal bleeding between menses as symptom of cervical cancer. $132(66 \%)$ knew symptom as foul-smelling vaginal discharge, $86(42 \%)$ as lower abdominal pain, $82(41 \%)$ as loss of appetite and weight while $52(26 \%)$ females knew the symptom as postcoital bleeding. $54(27 \%)$ respondents knew that pap smear test should be done as screening test to detect cervical cancer in early stage while $22(11 \%)$ respondents knew about HPV vaccine as preventive measure.

Conclusions: Recognition of cervical cancer risk factors and symptoms was low among study participants. Targeted interventions including increasing availability of HPV vaccination, population-based cervical screening and diagnostic services can translate high awareness into actual benefits.

Keywords: Cervical cancer, Cure, Knowledge, Perception, Prevention

\section{INTRODUCTION}

Cervical cancer is a leading cause of morbidity and mortality among women in the low- and middle-income countries. Of 500000 new cervical cancer cases diagnosed annually worldwide, $83 \%$ occurred in low- and middle-income countries. In these countries, more than $80 \%$ are diagnosed at advanced stage and have poor prognosis. ${ }^{1}$ Almost all cervical cancers are caused by human papilloma virus (HPV) HPV virus can be passed from one person to another during sex. There are many types of HPV. Some HPV types can cause changes on a woman's cervix. These changes can lead to cervical cancer over time. Other types can cause genital or skin warts. $^{2}$

Apart from HPV virus, following factors increase risk of cervical cancer:

- $\quad$ Smoking

- HIV virus infection and AIDS)

- Use of birth control pills for five or more years 
- Multiparity

- $\quad$ Multiple sexual partners. ${ }^{2}$

High incidence and mortality from cervical cancer in subSaharan Africa is due to lack of awareness of cervical cancer among the population, health-care providers and policymakers. Limited access to high-quality health-care services and cervical screening programmes; and lack of functional referral systems also contribute. All these lead to diagnosis at advanced stage. ${ }^{3}$

Sexually transmitted infection with human papilloma virus (HPV) is the main cause of carcinoma of the cervix. HPV prevalence increases with multiple sexual partners and poor genital hygiene. Of the $100 \mathrm{HPV}$ types, 16 and 18 have been categorized as high-risk types for cervical cancer. ${ }^{4}$

HPV types 16 and 18 account for almost $70 \%$ of all cervical cancer cases in India. $^{5}$

Cervical cancer is the leading cancer among women in India. Most important is that this disease is preventable if detected early. In low resource settings such as India implementation of universal screening is still not possible. This is due to lack of trained manpower and resources. Time tested screening methods are cervical cytology, aided visual inspection of the cervix and human papilloma-virus tests. ${ }^{6}$

A Pap test is preventive. It aims not to detect cancer and also reveal any cell changes that indicate that cancer could develop, so that early action can be taken. ${ }^{7}$

The most common symptoms of cervical cancer are:

- Bleeding apart from periods

- Postcoital bleeding

- Post-menopausal bleeding

- Discomfort during sexual intercourse

- Foul smelling vaginal discharge

- Blood stained vaginal discharge

- Abdominal and pelvic pain. ${ }^{7}$

After an educational intervention in India, there was increasing awareness about cervical cancer symptoms up to $76 \%$ in a community as compared to $25 \%$ in the control community. It was associated with significant change in stages at presentation of cervical cancer from $38 \%$ in stages I and II before the intervention to $51 \%$ in stages I and II after the intervention. ${ }^{8}$

The objectives of the present study were to know the knowledge about cervical cancer among women attending OPDs of hospitals. To assess the knowledge level regarding symptoms, risk factors, prevention and screening of cervical carcinoma among women. To know about the awareness of cervical cancer screening among these women and the facilities available for it, and to explore the sources of information.

\section{METHODS}

It was a cross sectional study conducted in the months of September and October 2017 at Narayan Medical College and Hospital, Jamuhar. We included 200 women between 30 and 60 years of age attending Gynecology OPD of a tertiary care hospital in rural.

\section{Inclusion criteria}

- Married women who were between 30 and 60 years of age

- Women who have given consent for participation in the study.

\section{Exclusion criteria}

- Women who were below 30 or above 60 years of age.

- Women who did not give consent for participation in the study.

- The questionnaire was designed based on cervical cancer awareness. It was pretested on a sample of 30 women to check for feasibility and reliability and modified accordingly for use in the study.

- They were interviewed with the questionnaire after getting informed verbal consent from all participants.

The responses were analyzed with descriptive statistics for percentages for categorical variables.

Table 1: Questionnaire.

Question
Name
Age
Do you know about cervical cancer?
Is it preventable?
Do you know about HPV vaccine?
Do you know about Pap smear test?
Is cervical cancer curable?

\section{RESULTS}

In present study, out of 200 females, 96 (48\%) were of 41-50 years age, 48 (24\%) were of 51-60 years while 36 (18\%) females were of $31-40$ years age.

Table 2: Age distribution.

\begin{tabular}{|lll|}
\hline Age distribution & No. of females & Percentage \\
\hline $31-40$ years & 36 & 18 \\
\hline $41-50$ years & 96 & 48 \\
\hline $51-60$ years & 48 & 24 \\
\hline
\end{tabular}


Majority of females were of 41-50 years of age followed by females of 41-50 years of age, (Table 2). In present study, source of information about cervical cancer in 124 $(62 \%)$ females was doctor. Source of information was friend in $60(30 \%)$ females, media like $\mathrm{TV} / \mathrm{radio} /$ newspaper in $10(5 \%)$ females and relative in 6 (3\%) females.

Table 3: Source of information.

\begin{tabular}{|l|l|l|}
\hline Source of information & No. of girls & Percentage \\
\hline Doctor & 124 & 62 \\
\hline Friend & 60 & 30 \\
\hline TV/ Radio/ Newspaper & 10 & 5 \\
\hline Relative & 6 & 3 \\
\hline
\end{tabular}

Majority of females got information from the doctor followed by a friend (Table 3). In present study, out of 200 respondents, $166(83 \%)$ had heard about cervical cancer, $24(12 \%)$ knew that cervical cancer can be cured if detected in early stage while only $10(5 \%)$ knew that it can be prevented.

In present study, awareness about the knowledge of cervical risk factors and symptoms was very good but not of prevention and cure (Table 4). In present study, out of 200 respondents, the risk factors for cervical carcinoma known to females were HPV infection in 30 (15\%), multiparity and reproductive tract infection in $24(12 \%)$ each, frequent childbirth in $22(11 \%)$, early marriage in $18(9 \%)$ and multiple sexual partners in $12(6 \%)$.

Table 4: Awareness of knowledge, prevention and cure of cervical cancer.

\begin{tabular}{|c|c|c|}
\hline $\begin{array}{l}\text { A wareness of knowledge, } \\
\text { prevention and cure of } \\
\text { cervical cancer }\end{array}$ & $\begin{array}{l}\text { No. of } \\
\text { females }\end{array}$ & Percentage \\
\hline Knowledge & 166 & 83 \\
\hline Prevention & 10 & 5 \\
\hline Cure & 24 & 12 \\
\hline
\end{tabular}

In present study, knowledge about all risk factors was very less (Table 5). In present study, out of 200 respondents, 158 (79\%) females knew vaginal bleeding between menses as symptom of cervical cancer.

Table 5: Awareness of risk factors for cervical cancer.

\begin{tabular}{|lll|}
\hline $\begin{array}{l}\text { A wareness of risk factors } \\
\text { for cervical cancer }\end{array}$ & $\begin{array}{l}\text { No. of } \\
\text { females }\end{array}$ & Percentage \\
\hline Early marriage & 18 & 9 \\
\hline Multiparity & 24 & 12 \\
\hline Frequent childbirths & 22 & 11 \\
\hline Multiple sexual partners & 12 & 6 \\
\hline HPV infection & 30 & 15 \\
\hline Reproductive tract infection & 24 & 12 \\
\hline
\end{tabular}

$132(66 \%)$ knew symptom as foul-smelling vaginal discharge, $86(42 \%)$ as lower abdominal pain, $82(41 \%)$ as loss of appetite and weight while $52(26 \%)$ females knew the symptom as postcoital bleeding.

In present study, vaginal bleeding was the commonest symptom known to females followed by lower abdominal pain and loss of appetite and weight (Table 6).

Table 6: Awareness of symptoms for cervical cancer.

\begin{tabular}{|lll|}
\hline $\begin{array}{l}\text { A wareness of symptoms } \\
\text { for cervical cancer }\end{array}$ & $\begin{array}{l}\text { No. of } \\
\text { females }\end{array}$ & Percentage \\
\hline $\begin{array}{l}\text { Vaginal bleeding between } \\
\text { menses }\end{array}$ & 158 & 79 \\
\hline Postcoital bleeding & 52 & 26 \\
\hline $\begin{array}{l}\text { Foul smelling vaginal } \\
\text { discharge }\end{array}$ & 132 & 66 \\
\hline Lower abdominal pain & 86 & 43 \\
\hline Loss of appetite and weight & 82 & 41 \\
\hline
\end{tabular}

In present study, out of 200 respondents, 54 (27\%) respondents knew that pap smear test should be done as screening test to detect cervical cancer in early stage while $22(11 \%)$ respondents knew about HPV vaccine as preventive measure.

So, in present study, awareness about pap smear and HPV vaccination both was very less (Table 7).

Table 7: Awareness of prevention of cervical cancer.

\begin{tabular}{|lll|}
$\begin{array}{l}\text { A wareness of prevention of } \\
\text { cervical cancer }\end{array}$ & $\begin{array}{l}\text { No. of } \\
\text { females }\end{array}$ & Percentage \\
\hline Pap smear & 54 & 27 \\
\hline HPV vaccination to daughters & 22 & 11 \\
\hline
\end{tabular}

\section{DISCUSSION}

In present study, out of 200 females, 96 (48\%) were of 41-50 years age, 48 (24\%) were of 51-60 years while 36 (18\%) females were of 31-40 years age (Table 2).

Dhodapkar SB et al reported that all the study participants were females. Majority of the participants $159(79.5 \%)$ were in the age group of $20-24$ years. $^{9}$

In present study, source of information about cervical cancer in $124(62 \%)$ females was doctor. Source of information was friend in $60(30 \%)$ females, media like $\mathrm{TV} / \mathrm{radio} /$ newspaper in $10(5 \%)$ females and relative in 6 (3\%) females (Table 3$)$.

In present study, out of 200 respondents, $166(83 \%)$ had heard about cervical cancer, 24 (12\%) knew that cervical cancer can be cured if detected in early stage while only $10(5 \%)$ knew that it can be prevented (Table 4). 
Dhodapkar SB et al reported that $85 \%$ were aware of the term cancer cervix and $45 \%$ reported that it is the most frequent gynaecological cancer in India. 30.6\% reported that it is the leading cause of death in women. ${ }^{9}$

In present study, out of 200 respondents, the risk factors for cervical carcinoma known to females were HPV infection in $30(15 \%)$, multiparity and reproductive tract infection in $24(12 \%)$ each, frequent childbirth in 22 (11\%), early marriage in $18(9 \%)$ and multiple sexual partners in $12(6 \%)$ (Table 5).

Dhodapkar SB et al reported that risk factors for cervical cancer were correctly reported as young age at first intercourse, multiple sex partners, cigarette smoking, high parity and lower socio-economic status by $13 \%$, $48 \%, 16 \%, 9 \%$ and $13 \%$ respectively. None of the participants knew about the VIA method of screening. Those participants who knew that cervical cancer can be detected by Pap smear, only 5 (4\%) had ever undergone Pap smear examination. ${ }^{9}$

Amos D et al found that $88.3 \%$ knew cervical cancer risk factors as multiple male sexual partners, sexually transmitted germ or virus $(82.0 \%)$. $48.6 \%$ knew multiparity, $48.6 \%$ as cigarette or tobacco smoking as risk factors for cervical cancer. ${ }^{10}$

In present study, out of 200 respondents, $158(79 \%)$ females knew vaginal bleeding between menses as symptom of cervical cancer. $132(66 \%)$ knew symptom as foul-smelling vaginal discharge, $86(42 \%)$ as lower abdominal pain, $82(41 \%)$ as loss of appetite and weight while $52(26 \%)$ females knew the symptom as postcoital bleeding (Table 6).

Shah $\mathrm{V}$ et al found that $69 \%$ of respondents had some knowledge of cervical carcinoma. 65 (94.2\%) respondents stated vaginal discharge as one of the symptoms, 86.9 as menstrual abnormality and 66.6 as pain as symptoms. Only eight $(11.5 \%)$ respondents were aware of multiple sexual partners as one of the risk factors. ${ }^{11}$ In present study, out of 200 respondents, 54 (27\%) respondents knew that pap smear test should be done as screening test to detect cervical cancer in early stage while $22(11 \%)$ respondents knew about HPV vaccine as preventive measure (Table 7).

Shah $\mathrm{V}$ et al found that respondents who had some knowledge regarding cervical carcinoma, 61 (88.4\%) had knowledge of Pap test as one of the preventive measures. Out of 61 staff nurses who knew about Pap test, only five $(8 \%)$ had undergone Pap test. ${ }^{11}$

Faizan $\mathrm{S}$ et al found that $1.8 \%$ did not know about cervical cancer. Only $23.3 \%$ were aware that cervical cancer is the most common cause of gynecological cancers. $26 \%$ knew it is second in rank in mortality. $78 \%$ were aware that infection is the most common cause of cervical cancer. $62 \%$ said that virus is the cause and $61 \%$ of the respondents knew that the virus is Human Papilloma Virus (HPV). Majority knew that it is sexually transmitted. Only $41 \%$ knew that it can be detected by PCR. Only $26 \%$ were aware of one or more risk factors. $37 \%$ knew Pap smear as a screening test. Only 37 out of 400 respondents were aware of the HPV vaccine. ${ }^{12}$

Aswathy $\mathrm{S}$. et al found that the knowledge factors included no symptoms in $91(37.1 \%)$, not knowing Pap test in $28(3.1 \%)$. Reasons for not doing Pap test included lack of time in $18(7.3 \%)$, financial reason in $14(5.7 \%)$ and lack of facility in the area in $3(1.2 \%)$. Two women said they 'did not get a chance to do it'. ${ }^{13}$

Aswathy S. et al found that $48.8 \%$ of the women were aware of symptoms of cervical cancer. The symptoms mentioned were bleeding in $289(35.7 \%)$ and pain in 70 (8.6\%). 89.2\% did not know any risk factor for cervical cancer. Lack of hygiene and multiple sexual contacts were the only two risk factors told by $32(3.9 \%)$ and 13 $(1.6 \%)$ respondents. respectively. $726(89.7 \%)$ did not know when it should be done, $23(2.8 \%)$ said it should be done only when there is any problem and $60(7.4 \%)$ said it should be done after age of 30 years. $12(1.5 \%)$ said it should be done monthly, $20(2.5 \%)$ said $1-2$ yearly and $23(28 \%)$ every 2 to 3 years. Thus, $92.8 \%$ had poor knowledge on the symptoms, risk factors, screening test, etc. ${ }^{13}$

O'Connor $\mathrm{M}$ et al found that in Ireland $30 \%$ of women doctors had never undergone a Pap test. ${ }^{14}$ Hadley DW et al found that in Pennsylvania in spite of free genetic counseling and testing, only $57 \%$ of individuals with a positive BRCA1/2 family mutation status participated in testing. ${ }^{15}$

Harsha Kumar HN et al found that majority of the women had poor knowledge about cervical cancer and its screening. $81.9 \%(68 / 83)$ of the women were not aware of facilities for screening. Lack of knowledge is reflected in poor understanding of symptoms. The source of information was mainly mass media. Majority of the women who had approached the doctors in the last 1 year $(89.3 \%(66 / 74)$ and in the last 5 years $(80.7 \% 67 / 83)$ were not told/educated about cervical cancer. For the same time, frames education about screening was provided to only about $6 \%(5 / 83)$ and $9.6 \%(8 / 83)$ women only. Few 7.2\% 6/83 women had undergone screening for cervical cancer. The reasons for not getting screened were as follows $\mathrm{n}(\%)$ : Absence of disease symptoms in 15 (18.1), not suggested by health professional 14 (16.9), lack of time 4 (4.8), fear of having a bad result 3 (3.6), fear of pain 1 (1.2), financial reason 1 (1.2), and embarrassment. ${ }^{16}$

\section{CONCLUSION}

Recognition of cervical cancer symptoms was high but of risk factors was less among study participants. Targeted interventions including increasing availability of HPV 
vaccination, population-based cervical screening and diagnostic services can translate high awareness into actual benefits.

Funding: No funding sources

Conflict of interest: None declared

Ethical approval: The study was approved by the Institutional Ethics Committee

\section{REFERENCES}

1. Sankaranarayanan R, Budukh AM, Rajkumar R. Effective screening programmes for cervical cancer in low- and middle-income developing countries. Bulletin of the World Health Organization, 2001;79: 954-62.

2. Division of Cancer Prevention and Control, Centers for Disease Control and Prevention, 2017

3. WHO. Comprehensive Cervical Cancer Control; A Guide to Essential Practice. Geneva, Switzerland: WHO Press, World Health Organization, 2006.

4. International Agency for research on cancer IARC Monographs on Evaluation of Carcinogenic Risks to Humans, Human Papilloma Virus. 2007;90

5. Bharadwaj M. Hussain, Nasare V, Das BC. HPV and HPV Vaccination issues in developing countries, Indian J Med Res. 2009;130(3):327-33.

6. Asthana S, Labani S. Factors associated with attitudes of rural women toward cervical cancer screening. Indian J Comm Medi. 2013;38(4):246.

7. Christian Nordqvist, What you need to know about cervical cancer, Medical News Today, Dec 2017

8. Jayant K, Rao RS, Nene BM, Dale PS. Improved stage at diagnosis of cervical cancer with increased cancer awareness in a rural Indian population. Int $\mathbf{J}$ Cancer, 1995;63(2):161-3.

9. Dhodapkar SB, Chauhan RC, Thampy S. Knowledge and awareness of cervical cancer and its prevention among nursing staff of a tertiary care teaching institute in South India. Int J Reprod Contracept Obstet Gynecol. 2014;3(4):1056-60.
10. Mwaka AD, Orach CG, Were EM, Lyratzopoulos G, Wabinga H, Roland M. Awareness of cervical cancer risk factors and symptoms: cross-sectional community survey in post-conflict northern Uganda. Health Expectations. 2016;19(4):854-67.

11. Shah V, Vyas S, Singh A, Shrivastava M. Awareness and knowledge of cervical cancer and its prevention among the nursing staff of a tertiary health institute in Ahmedabad, Gujarat, India. ecancermedicalscience. 2012;6.

12. Ali SF, Ayub S, Manzoor NF, Azim S, Afif M, Akhtar N, Jafery WA, Tahir I, Farid-ul-Hasnian S, Uddin N. Knowledge and awareness about cervical cancer and its prevention amongst interns and nursing staff in Tertiary Care Hospitals in Karachi, Pakistan. PloS one. 2010;5(6):e11059.

13. Aswathy S, Quereshi M A, Kurian B, Leelamoni K. Cervical cancer screening: Current knowledge and practice among women in a rural population of Kerala, India. Indian $\mathbf{J}$ Med Res. Aug 2012;136(2):205.

14. O'Connor M, Kelleher C, Do doctors benefit from their profession? A survey of medical practitioners' health safety practices, Ir Med J. 1998;91:206-9

15. Hadley DW, Jenkins J, Dimond E, Nakahara K, Grogan L, Liewehr DJ et al. Genetic counseling and testing in families with hereditary nonpolyposis colorectal cancer. Arch Int Med. 2003;163(5):57382.

16. Harsha Kumar HN, Tanya S. A study on knowledge and screening for cervical cancer among women in Mangalore city. Ann Med Health Sci Res 2014;4(5):751-6.

Cite this article as: Singh S, Narayan N, Sinha R, Sinha P, Sinha VP, Upadhye JJ. Awareness about cervical cancer risk factors and symptoms. Int J Reprod Contracept Obstet Gynecol 2018;7:4987-91. 